\title{
STEREOCONTROLLED SYNTHESIS OF NEW TETRAHYDROFURO[2,3-d]THIAZOLE DERIVATIVES VIA ACTIVATED VINYLOGOUS IMINIUM IONS
}

Rade Marković, ${ }^{* a, b}$ Marija Baranac, ${ }^{a, b}$ Peter J. Steel, ${ }^{c}$ Erich Kleinpeter ${ }^{d}$ and Milovan Stojanovićb

${ }^{a}$ Faculty of Chemistry, University of Belgrade, Studentski trg 16, P. O. Box 158, 11001 Belgrade, Serbia and Montenegro

${ }^{\mathrm{b}}$ Center for Chemistry ICTM, P. O. Box 815, 11000 Belgrade, Serbia and Montenegro

${ }^{c}$ Department of Chemistry, University of Canterbury, P.O. Box 4800, Christchurch, New Zealand

${ }^{\mathrm{d}}$ Universität Potsdam, Chemisches Institut, P.O. Box 60 15 53, D-14415 Potsdam, Germany

Abstract-Intramolecular heterocyclization of (Z)-5-(2-hydroxyethyl)-3-methyl-4-oxothiazolidines, bearing electron-withdrawing groups conjugated to an exocyclic double bond at $\mathrm{C}(2)$-position, afforded under reductive conditions, not easily accessible cis-tetrahydrofuro[2,3- $d]$ thiazole derivatives. The reactions of these functionalized push-pull $\beta$-enamines occur in a stereocontrolled fashion via activated vinylogous $N$-methyliminium ions, which are trapped by an internal hydroxyethyl group.

Key words: Thiazolidines, vinylogous $N$-iminium ion, heterocyclization,

\section{Introduction}

In recent years, a variety of acyclic and cyclic iminium ions with a nucleophilic tether, exemplified by general structures 1 and 3 (Scheme 1), have been successfully used for heterocyclization reactions giving rise to nitrogen-containing heterocycles $\mathbf{2}$ and $\mathbf{4}$, respectively. ${ }^{1}$

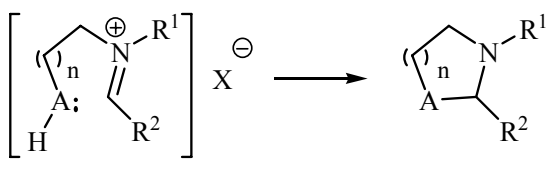

1

2

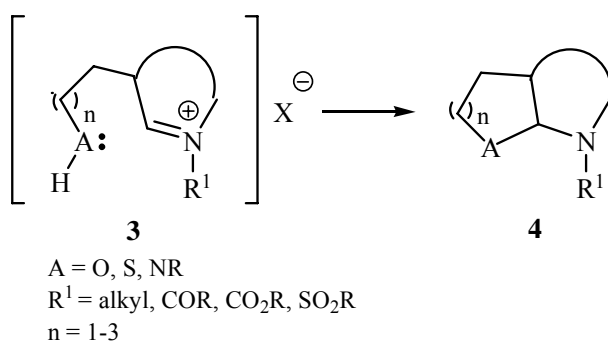

\section{Scheme 1}

\footnotetext{
${ }^{*}$ Corresponding author. Tel.: +38-11-3282-111 (ext. 741); fax: +38-11-636-061; e-mail: markovic@helix.chem.bg.ac.yu
} 
An abundance of strategic preparations of different ring systems with five to eight atoms, based on an endo-mode cyclization of iminium ion $\mathbf{1}$, bearing properly located oxygen, ${ }^{2}$ sulfur $^{3}$ or nitrogen ${ }^{4}$ as heteroatom, or nonaromatic and aromatic $\mathrm{C}=\mathrm{C}$ bond as a $\pi$-nucleophile, ${ }^{5}$ has confirmed a wide scope of this process. Likewise, the literature documents that numerous synthetically and medicinally important condensed heterocycles, can be derived by an exo-type cyclization of the key cyclic intermediate $3 .^{6}$ Extensive experimental evidence underlines the correlation between the presence of electron-withdrawing groups (EWG), such as the acyl, tosyl, COOR or $\mathrm{CONR}_{2}$, at the nitrogen atom of iminium ions $\mathbf{1}$ and 3 , and their increasing cationic character, thus, making them more reactive toward nucleophiles. ${ }^{1,7}$ The synthetic utility of vinylogous iminium ions 5 for ring closure reactions has been also examined, however, in an exceedingly limited number of cases ${ }^{8}$ (Scheme 2). Within this context, Hart ${ }^{8 a}$ has reported one of the rare examples when a vinylogous iminium ion 6 undergoes intramolecular $\pi$-cyclization, forming a useful tricyclic intermediate 7 , en route to envisioned synthesis of the alkaloid depentylperhydrogephyrotoxin $\mathbf{8} .^{9}$
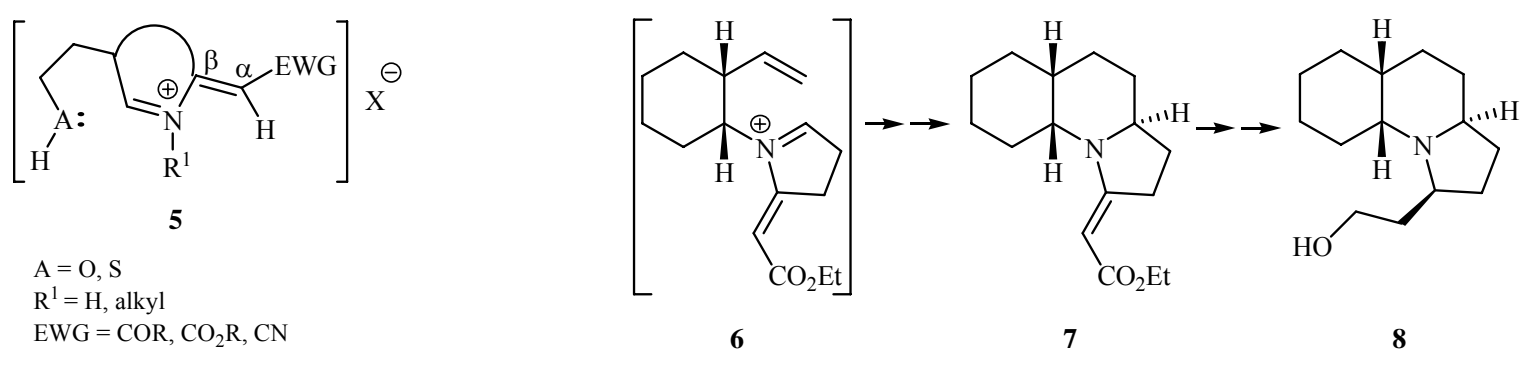

Scheme 2

Now we wish to demonstrate an ability of new vinylogous $\mathrm{N}$-alkyliminium ions of type $\mathbf{5}$, possessing the hydroxyethyl group as an internal nucleophile $\left(\mathrm{A}=\mathrm{O} ; \mathrm{R}^{1}=\mathrm{Me}\right)$, to participate in heterocyclization, that is, as one would anticipate, strongly driven by the presence of various electron-withdrawing groups at the $\alpha$-position of the $\mathrm{C}=\mathrm{C}$ bond. Therefore, our studies, described below, represent to the best of our knowledge, (i) the first example of 5exo-trig intramolecular cyclization of push-pull 3-methyl-(Z)-4-oxothiazolidine alcohols 12a-d, obtained from 2-alkylidene-5-carboethoxymethyl-4-oxothiazolidines 9a-d, ${ }^{10}$ to new cis-condensed thiazolidine compounds 13a-d (Scheme 3), including (ii) the determination of the stereochemistry by a single-crystal X-ray analysis of a representative of the series, cis-(Z)-2-(tetrahydro-3-methylfuro[2,3- $d]$ thiazol-2(5H)-ylidene)-1-phenylethanone (13a). 


\section{Results and discussion}

In our preliminary study, ${ }^{11}$ thiazolidine $\beta$-enamino derivatives 9a-d, containing the carboethoxymethyl substituent at $\mathrm{C}(5)$ position, were found to react with $\mathrm{NaBH}_{4}$ in ethanol to afford in chemoselective fashion the corresponding alcohols 11a-d $(\mathrm{R}=\mathrm{H})$. To our surprise $N$-methyl substituted 4-oxothiazolidine derivative 10a having the $(Z)$-configuration, presently confirmed by a single-crystal X-ray structure (Figure 1), was converted under analogous conditions into the bicyclic product 13a, albeit in a small yield (21\%).

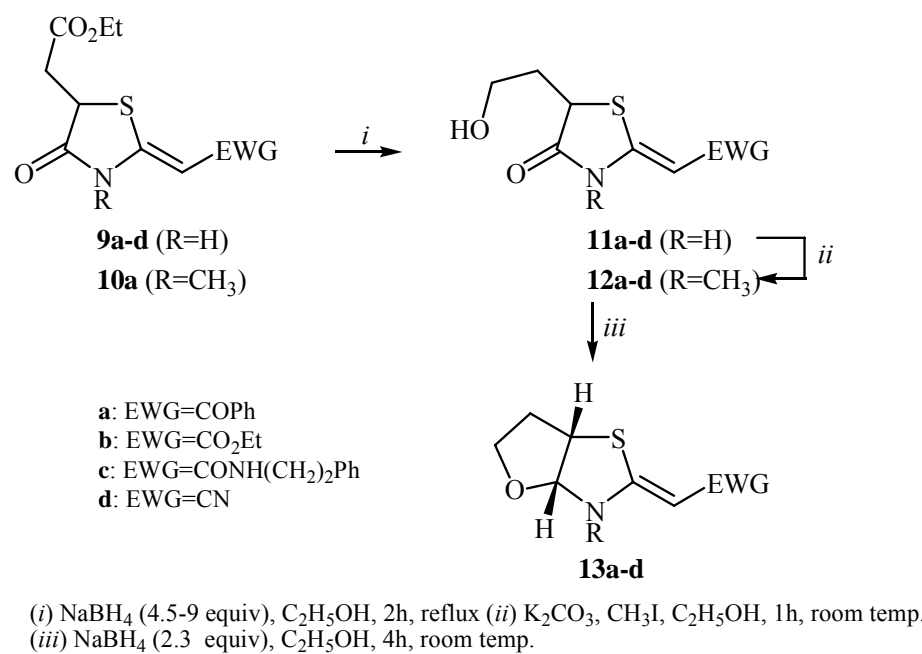

\section{Scheme 3}

Despite the considerable amounts of other products being formed (vide infra), this result prompted us to further explore whether the thiazolidines 9a-d can be employed for the synthesis of not easily obtainable bicyclic products 13 a-d ${ }^{12}$ via a reduction-alkylation-ring closure sequence, involving the $\mathrm{C}(5)$ and $\mathrm{C}(4)$ positions of the starting derivatives. ${ }^{13}$

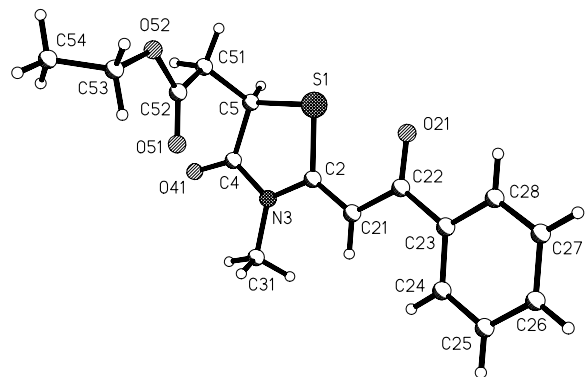

Figure 1. Perspective view of the crystal structure of (Z)-(5-ethoxycarbonylmethyl-3-methyl-4-oxothiazolidin-2-ylidene)-1-phenylethanone (10a), showing the crystallographic numbering scheme. Selected bond lengths ( $\AA$ ): S1-C2 1.755(2), S1-C5 1.820(2), C2-N3 1.388(2), C2-C21 1.358(2), N3-C4 1.378(2), C4-O41 $1.220(2), \mathrm{C} 4-\mathrm{C} 5$ 1.512(2), C21-C22 1.446(2). The $\mathrm{S} 1 \cdots \mathrm{O} 21$ non-bonded distance is 2.605(1) $\AA$. 
Precursors 9a-d, required for the synthesis of 11a-d with built-in alcohol nucleophiles, were obtained by known base-catalyzed reactions of $\beta$-oxonitriles and diethyl mercaptosuccinate. ${ }^{10}$ The unambiguous assignment of the $(\mathrm{Z})$-configuration to the exocyclic $\mathrm{C}=\mathrm{C}$ bonds of compounds 9a-c has been established by NOE correlations and crystallographic studies, ${ }^{10 \mathrm{~b}}$ whereas the heterocycle 9d, having the nitrile substituent as EWG, was obtained as a mixture of both isomers. As indicated above, the regioselective reduction of the sidechain acetate group in 9a-d with excess $\mathrm{NaBH}_{4}$ gave rise to alcohols 11a-d in good yields (49-64\%), without affecting the enaminone moiety, or affording the products of reductive ring opening. The resistance of this structural fragment to reduction by metal hydrides or catalytic reduction, is considered to reside in strong deactivation of EWG function and $\mathrm{C}=\mathrm{C}$ bond due to resonance delocalization. ${ }^{11,14}$ Standard alkylation of the $(Z)-11 \mathbf{a}-\mathbf{c}$, afforded, without configuration change, the corresponding 3-methyl-4-oxothiazolidine alcohols 12a-c (Table 1, 78-92\%) This is expected in view of the greater stability of (Z)-configurated thiazolidines 9a-c in the solid state and in polar solvents, versus the $(E)$-analogs, particularly due to the strong nonbonded electrostatic S---O interaction of the 1,5-intratype in the former isomers. ${ }^{15}$ Interestingly, $\mathbf{1 2 d}(\mathrm{EWG}=\mathrm{CN})$ was also isolated as a single (Z)-isomer. Apparently, the steric bias provided by the $N$-methyl substituent is sufficient to fix the (Z)-configuration. The ring closure upon treatment of 12a-d with $\mathrm{NaBH}_{4}$ in ethanol at room temperature, proceeded in a stereocontrolled manner, and the cis-fused products 13a-d were isolated after preparative TLC purification as single $Z$-isomers, in reasonable yields (36-56\%, Table 1). Besides the elemental analyses, the spectroscopic results are fully consistent with the structures of the new bicyclic products 13a-d. The IR spectra of 13a-d, recorded in the solid state (KBr pellet) show a strong band within the 1080-1030 $\mathrm{cm}^{-1}$ range due to the characteristic asymmetric stretching of the $\mathrm{C}-\mathrm{O}$ bond in the tetrahydrofuran ring. Another diagnostic and strong band at $\sim 1580 \mathrm{~cm}^{-1}$, present in all IR spectra of derivatives 13a-d, is assigned to the exocyclic $\mathrm{C}=\mathrm{C}$ bond of an enamine moiety. ${ }^{16}$ The two five-membered rings are cis-fused. The conclusive structural evidence stems from ${ }^{1} \mathrm{H}-\mathrm{NMR}$ data: the vicinal coupling constants $J_{\mathrm{Xz}}$ being alike $(6.2-6.6 \mathrm{~Hz})$ in all bicyclic structures (Table 1, entries 2,4,6 and 8) closely match those of comparable systems reported previously. ${ }^{12 \mathrm{c}-\mathrm{e}}$ In addition, the cis-geometry was also supported by the $H H$ ROESY experiment. Thus, the proton attached to C-6a of 13a which resonates at $\delta$ 4.12, assuming the $\beta$-orientation, exhibits NOE interactions with $\mathrm{H}-3 \mathrm{a}$ and $\mathrm{H}-6$ positioned 
at the $\beta$-face. From the $H H$ ROESY spectrum of 13a the correlation between the $\mathrm{N}-\mathrm{CH}_{3}$ and vinyl proton confirmed the $(\mathrm{Z})$-configuration of the $\mathrm{C}=\mathrm{C}$ bond.

Table 1. Yields and selected ${ }^{1} \mathrm{H}$ and ${ }^{13} \mathrm{C}$ NMR chemical shifts (ppm) of 4-oxothiaziolidine alcohols 12a-d in DMSO- $d_{6}$ and bicyclic thiazolidine derivatives 13a-d in $\mathrm{CDCl}_{3}$
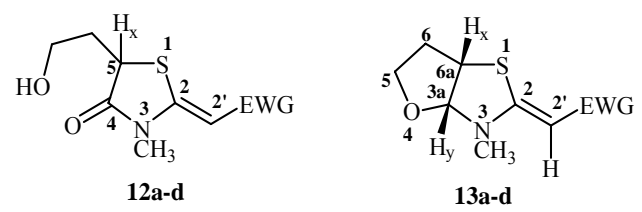

\begin{tabular}{|c|c|c|c|c|c|c|c|c|c|}
\hline Entry & Compound/EWG & $=\mathrm{CH}$ & $\mathrm{H}_{\mathrm{X}}$ & $\mathrm{H}_{\mathrm{Y}}$ & $J_{X Y}(\mathrm{~Hz})$ & $\mathrm{C}(2)$ & $=\mathrm{CH}$ & $\Delta \delta_{\mathrm{C} 2 \mathrm{C} 2^{\prime}}$ & Yield $(\%)^{\mathrm{a}}$ \\
\hline 1 & $(Z)-12 a / C O P h$ & 6.92 & $4.12^{\mathrm{b}}$ & & & 161.4 & 95.4 & 66.0 & 86 \\
\hline 2 & (Z)-13a /COPh & 6.04 & 4.12 & 5.67 & 6.5 & 165.7 & 87.5 & 78.0 & 56 \\
\hline 3 & (Z)-12b $/ \mathrm{CO}_{2} \mathrm{Et}$ & 5.57 & $4.12^{\mathrm{b}}$ & & & 158.5 & 89.4 & 69.1 & 92 \\
\hline 4 & $(Z)-\mathbf{1 3 b} / \mathrm{CO}_{2} \mathrm{Et}$ & 4.84 & 4.10 & 5.61 & 6.2 & 162.9 & 79.6 & 83.3 & 36 \\
\hline 5 & (Z)-12c /CONH $\left(\mathrm{CH}_{2}\right) \mathrm{Ph}$ & 5.55 & $3.97^{\mathrm{b}}$ & & & 166.1 & 93.2 & 72.9 & 78 \\
\hline 6 & $(\mathrm{Z})-\mathbf{1 3 c} / \mathrm{CONH}\left(\mathrm{CH}_{2}\right) \mathrm{Ph}$ & 4.67 & 4.06 & 5.55 & 6.2 & 166.0 & 82.2 & 83.8 & 40 \\
\hline 7 & $(Z)-12 d / C N$ & 5.27 & $4.41^{\mathrm{b}}$ & & & 160.4 & 67.1 & 93.3 & 80 \\
\hline 8 & $(Z)-\mathbf{1 3 d} / \mathrm{CN}$ & 3.94 & 4.25 & 5.65 & 6.6 & 160.8 & 55.8 & 105.0 & 40 \\
\hline
\end{tabular}

${ }^{\text {a }}$ Yields refer to pure isolated products.

${ }^{\mathrm{b}}$ Part of an ABX spin-coupling system with protons of the neighboring methylene group.

The selected ${ }^{13} \mathrm{C}$ NMR shift differences between the olefinic carbon atoms, i.e. $\Delta \delta_{\mathrm{C}(2) \mathrm{C}\left(2^{\prime}\right)}$ values in compounds 12 and 13 are worth noting (Table 1). They indicate a charge separation of $\mathrm{C}=\mathrm{C}$ bond as a measure of the push-pull character ${ }^{17}$ within the condensed thiazolidines 13, relative to 4-oxothiazolidine alcohols 12. Larger $\Delta \delta_{\mathrm{C}(2) \mathrm{C}\left(2^{\prime}\right)}$ values $(78-82$ ppm) in the bicyclic derivatives 13a-d from 78-105 ppm, respectively (Table 1, entries 2,4,6 and 8) versus the corresponding $\Delta \delta_{\mathrm{C}(2) \mathrm{C}\left(2^{\prime}\right)}$ values $(66-93 \mathrm{ppm})$ in alcohols 12a-d (Table 2, entries 1,3,5 and 7) correlate with an increase of the push-pull effect in $13 .{ }^{18} \mathrm{An}$ explanation is in accord with the presence of the more effective electron-donor (i.e. an amine) in the fused thiazolidines $\mathbf{1 3}$ in comparison to an amide functionality in substrates $\mathbf{1 2}$. Further evidence, supporting unequivocally the cis-ring juncture stereochemistry and (Z)configuration assigned to 13a-d, was provided by an X-ray crystal structure analysis of the representative of the series 13a (Figure 2).

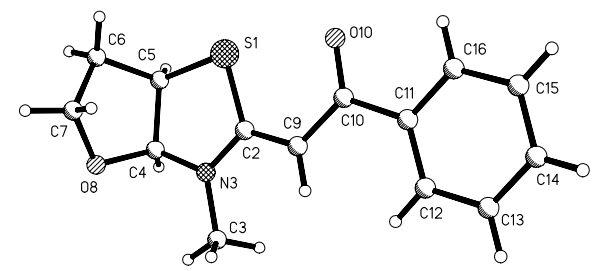

Figure 2. Perspective view of the crystal structure of $(Z)$-2-(tetrahydro-3-methylfuro[2,3- $d$ ] thiazol-2(5H)-ylidene)-1-phenylethanone (13a). Selected bond lengths (A): S1-C2 1.746(1), S1-C5 1.828(1), C2-N3 1.347(2), C2-C9 1.381(2), N3-C4 1.451(2), C4-O8 1.420(2), C4-C5 1.544(2), C9-C10 1.426(2). 
Compound 13a crystallizes in the space group $\mathrm{P} 2{ }_{1} / \mathrm{c}$, but with two molecules in the asymmetric unit. Figure 2 shows a perspective view of one molecule with selected bond lengths. The geometries of the two independent molecules are almost identical. The crystal structure confirms the geometry of the fused-ring junction (cis) and the exocyclic double bond $(Z)$. The thiazolidine ring is almost planar cis (mean deviation from the meanplane = 0.013 and $0.18 \AA$, for the two independent molecules) as a consequence of containing an unsaturated linkage. The conformation of the side chain is similar to that in 10a (Figure 1), although the non-bonded S-O distance ${ }^{10 b, 18}$ has increased slightly to 2.724(1) and 2.729(1) $\AA$, for the two independent molecules.

In accordance with the spectroscopic results, semiempirical calculations with MOPAC (PM3, geometry optimisation) and ab initio calculations with Gaussian (HF, 6-31G*, geometry optimisation) show that the cis-isomers 13a-d are preferred from an energetic point of view. As exemplified for 13a, the $c i s$-isomer is $19.5 \mathrm{kcal}$ more stable as calculated by MOPAC, or $16.5 \mathrm{kcal}$ according to a Gaussian calculations (Figure 3).

trans-Isomer 13a

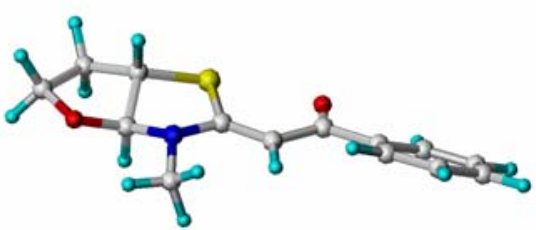

cis-Isomer 13a

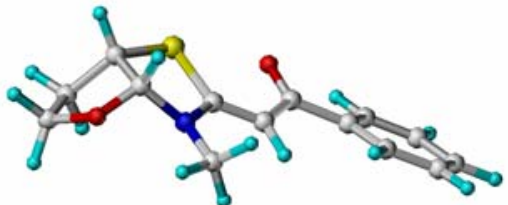

Figure 3. The cis- and trans-configurations of 13a

Visual inspection of the three-dimensional models depicted in Fig. 3 clearly indicate that the large energy difference should be attributed to a combination of severe angle strain and nonbonded transannular repulsion imposed upon a trans-fusion of the almost flat thiazolidine ring to the tetrahydrofuran ring. As a result, the thiazolidine ring in the trans-fused compound 13a is forced to adopt a relatively nonplanar conformation, where there is no optimal conjugation between nitrogen (and sulfur) and EWG through the intervening $\mathrm{C}=\mathrm{C}$ bond. Release of the angle strain-constraint in the cis-arrangement of the two fivemembered rings, in combination with the resonance effect attenuation, is responsible for this exclusive lower energy configuration of the cis-isomer 13a.

On the basis of the experiments presented here, and numerous regioselective hydride reduction of ring substituted cyclic imides to hydroxy lactams, ${ }^{1 \mathrm{c}, 6 \mathrm{a}, \mathrm{b}, 8 \mathrm{~d}, 19 \mathrm{a}}$ it is clear that the reduction of 4-oxothiazolidine alcohols 12 with $\mathrm{NaBH}_{4}$ in ethanol leads, in a first step, to in situ formation of a diol 14 (Scheme 4). 

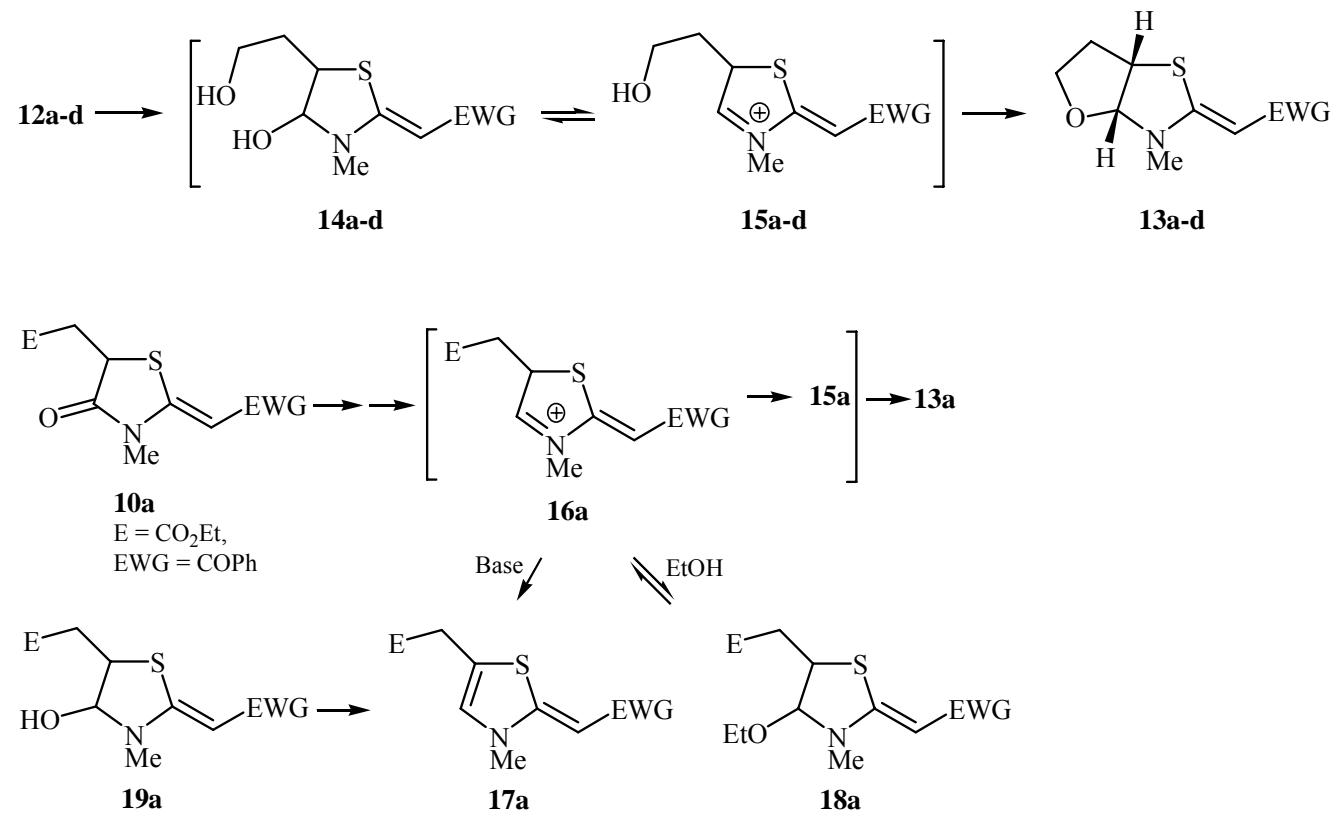

Scheme 4

This initial step sets the stage for the conversion of the diol 14 into the vinylogous $\mathrm{N}$ methyliminium ion 15, having the incorporated hydroxyethyl group at the $\mathrm{C}(5)$-position as a reactive nucleophile. Subsequent intramolecular 5-exo-trig heterocyclization by nucleophilic attack onto the iminium $\pi$-bond affords the cis-fused tetrahydrofurothiazolidine 13. In general, it has been found that $N$-acyliminium ion cyclization gives rise to a lower yield if the iminium carbon atom is bonded to a carbon-carbon double or triple bond. ${ }^{20}$ However, our experimental results indicate that ring closure of vinylogous methyliminium ion $\mathbf{1 5}$ is assisted by the electron-withdrawing group at the $\alpha$-carbon atom of the exocyclic $\mathrm{C}=\mathrm{C}$ bond. The aforementioned cis-disposition of the angular hydrogens in the transition-state structure and in the product $\mathbf{1 3}$ involves the minimization of angular strain, thus dictating the stereochemical course of the reaction. The heterocyclization selectivity regarding the 15 $\rightarrow$ 13 step has been already established for cyclizations leading to similar bicyclic system. ${ }^{12 \mathrm{c}-\mathrm{e}}$ Additional evidence regarding the postulated iminium ion $\mathbf{1 5}$ as a key intermediate has been obtained in direct heterocyclization of the $N$-methyl-4-oxothiazolidine 10a to $13 a$ ( $21 \%$ yield) under reductive conditions (Scheme 2 ). The formation of by products, 3-methylthiazole derivative 17a (18\%) and 4-ethoxy-3-methylthizolidine derivative 18a $(1-2 \%)$, is consistent with the presence of $\mathbf{1 6 a}$ as a transient species, thereby also leading to 13a via 15a. Another distinct pathway to the double enamine species 17a, involves dehydration of a hydroxythiazolidine 19a, obtained by initial hydride reduction of 10a, thus, reducing the yield of cyclization product $13 \mathbf{a} .^{20}$ 
In summary, the study on the intramolecular heterocyclization of (Z)-5-(2-hydroxyethyl)-3methyl-4-oxothiazolidines, giving rise to new stereodefined tetrahydrofuro[2,3- $d]$ thiazole derivatives, has been presented. The scope and mechanism of this transformation, involving a new type of vinylogous $\mathrm{N}$-methyliminium ion, possessing the hydroxyethyl group as the internal nucleophile and different electron-withdrawing groups, at the $\alpha$-position of the exocyclic $\mathrm{C}=\mathrm{C}$ bond, were also studied.

\section{Experimental}

Melting points were determined on a Micro-Heiztisch Boetius PHMK apparatus or B $\eta$ chi apparatus and are uncorrected. The IR spectra were recorded on a Perkin-Elmer FT-IR $1725 \mathrm{X}$ spectrophotometer and are reported as wave numbers $\left(\mathrm{cm}^{-1}\right)$. Samples for IR spectral measurements were prepared as $\mathrm{KBr}$ disks. The NMR spectra were obtained using a Varian Gemini 2000 instrument $\left({ }^{1} \mathrm{H}\right.$ at $200 \mathrm{MHz},{ }^{13} \mathrm{C}$ at $\left.50.3 \mathrm{MHz}\right) \cdot{ }^{13} \mathrm{C}$ NMR resonance assignments were aided by the use of the DEPT technique to determine numbers of attached hydrogens. ROESY have been performed..... Chemical shifts are reported in parts per million ( $\mathrm{ppm})$ on the $\delta$ scale from TMS as an internal standard in the solvents specified. Low-resolution mass spectra were recorded using a Finnigan MAT 8230 BE spectrometer at $70 \mathrm{eV}$ (EI). Isobutane was used as the ionizing gas for the chemical ionization (CI) mass spectra. The UV spectra were measured on a Beckman DU-50 spectrophotometer. Analytical thin-layer chromatography (TLC) was carried out on Kieselgel G nach Stahl, and the spots were visualized by iodine. Column chromatography was carried out on $\mathrm{SiO}_{2}$ (silica gel $60 \AA \AA, 12-26$, ICN Biomedicals). Elemental analyses were performed at the microanalysis laboratory at the Department of Chemistry, University of Belgrade.

\subsection{General procedure for the preparation of 3-methyl-4-oxothiazolidine alcohols 12a-d}

To a stirred solution of 4-oxothiazolidine alcohol $11(0.5 \mathrm{mmol})$ and $\mathrm{K}_{2} \mathrm{CO}_{3}(0.5 \mathrm{mmol})$ in dry acetone $(3-5 \mathrm{~mL})$, protected by aluminum foil, a $10 \%$ molar excess of $\mathrm{MeI}(0.55$ mmol) in acetone $(\sim 1-1.5 \mathrm{~mL})$ was added in one portion at $\mathrm{rt}$. The progress of the reaction was followed by TLC. The reaction mixture was refluxed for an additional 1-2.5 h until consumption of starting material. After evaporation of solvent under reduced pressure, the crude residue was purified by column chromatography (silica gel; toluene/ethyl acetate gradient 100:0 to 50:50, v/v) to afford 3-methyl-4-oxothiazolidine alcohols 12. Annalytically pure sample was obtained by crystallization from toluene in the case of 12a, 12b and 12d or from chloroform $/ n$-hexane mixture for 12c.

\subsection{1. (Z)-5-(2-Hydroxyethyl)-3-methyl-4-oxothiazolidin-2-ylidene)-1- phenylethanone (12a).}

The title compound was obtained as a white solid in $86 \%$ yield $(90 \mathrm{mg})$ from $100 \mathrm{mg}(0.38$ mmol) of 11a and $60 \mathrm{mg}(0.027 \mathrm{~mL}, 0.42 \mathrm{mmol})$ of methyl iodide. Mp 134-135 ${ }^{\circ} \mathrm{C}$; IR $(\mathrm{KBr}): v_{\max } 3412,3065,2922,2865,1690,1626,1575,1510,1464,1423,1349,1225$, 1128, 1052, 695, $632 \mathrm{~cm}^{-1}$; ${ }^{1} \mathrm{H}$ NMR (DMSO-d $\left.d_{6}\right): \delta 1.75-1.93\left(1 \mathrm{H}, \mathrm{m}, \mathrm{CH}_{\mathrm{A}} \mathrm{H}_{\mathrm{B}} \mathrm{CH}_{\mathrm{X}} \mathrm{S}\right)$,

2.16-2.31 $\left(1 \mathrm{H}, \mathrm{m}, \mathrm{CH}_{\mathrm{A}} \mathrm{H}_{\mathrm{B}} \mathrm{CH}_{\mathrm{X}} \mathrm{S}\right.$; the coupling constants of $\mathrm{H}_{\mathrm{A}}$ and $\mathrm{H}_{\mathrm{B}}$ protons cannot be 
determined as signals are of higher order), $3.27\left(3 \mathrm{H}, \mathrm{s}, \mathrm{NCH}_{3}\right), 3.59\left(2 \mathrm{H}, \mathrm{m}, \mathrm{CH}_{2} \mathrm{OH}\right), 4.12$ $\left(1 \mathrm{H}, \mathrm{dd}, J_{\mathrm{AX}}=4.8 \mathrm{~Hz}, J_{\mathrm{BX}}=4.2 \mathrm{~Hz}, \mathrm{CH}_{\mathrm{A}} \mathrm{H}_{\mathrm{B}} \mathrm{CH} H_{\mathrm{X}} \mathrm{S}\right), 4.80(1 \mathrm{H}$, broad t, OH), $6.92(1 \mathrm{H}, \mathrm{s}$, $=\mathrm{CH}), 7.47-7.63(3 \mathrm{H}, \mathrm{m}, p-\mathrm{Ph}$ and $m-\mathrm{Ph}), 7.83\left(2 \mathrm{H}, \mathrm{dd}, J_{o, m}=7.8 \mathrm{~Hz} ; J_{o, p}=1.8 \mathrm{~Hz}, o-\mathrm{Ph}\right)$; ${ }^{13} \mathrm{C}$ NMR (DMSO- $\left.d_{6}\right): \delta 30.4\left(\mathrm{NCH}_{3}\right), 35.9\left(\mathrm{CH}_{\mathrm{A}} \mathrm{H}_{\mathrm{B}}\right), 42.8\left(\mathrm{CH}_{\mathrm{X}}\right), 58.5\left(\mathrm{CH}_{2} \mathrm{OH}\right), 95.4$ $(=\mathrm{CH}), 127.7(m-\mathrm{Ph}), 128.8(o-\mathrm{Ph}), 132.4(p-\mathrm{Ph}), 138.5\left(\mathrm{C}_{1}-\mathrm{Ph}\right), 161.4(\mathrm{C}=), 175.3$ (CO lactam), 187.5 (CO $\left.\mathrm{CO}_{\text {ketone}}\right)$; MS (CI): $m / z 278\left(\mathrm{M}^{+}+1\right)$; UV (DMSO): $\lambda_{\max }(\varepsilon) 333.9 \mathrm{~nm}$, $(33,600)$. Anal. Calcd for $\mathrm{C}_{14} \mathrm{H}_{15} \mathrm{NO}_{3} \mathrm{~S}$ : C, 60.63; H, 5.45; N, 5.05; S, 11.56; Found: $\mathrm{C}$, $60.58 ; \mathrm{H}, 5.48 ; \mathrm{N}, 5.12 ; \mathrm{S}, 11.80$.

\subsubsection{Ethyl (Z)-(5-(2-Hydroxyethyl)-3-methyl-4-oxothiazolidin-2-ylidene)ethanoate (12b).}

The title compound was obtained as a white solid in $92 \%$ yield $(49 \mathrm{mg})$ from $50 \mathrm{mg}(0.22$ mmol) of $11 \mathrm{~b}$ and $34 \mathrm{mg}(0.015 \mathrm{~mL}, 0.24 \mathrm{mmol})$ of methyl iodide. Mp 87-89 ${ }^{\circ} \mathrm{C}$; IR $(\mathrm{KBr}): v_{\max } 3352,3065,2975,2931,1711,1684,1575,1472,1366,1333,1279,1175$, 1122, 1044, 862, 791, $768 \mathrm{~cm}^{-1} ;{ }^{1} \mathrm{H}$ NMR (DMSO- $\left.d_{6}\right): \delta 1.20\left(3 \mathrm{H}, \mathrm{t}, J=7.2 \mathrm{~Hz}, \mathrm{CH}_{2} \mathrm{CH}_{3}\right.$ ) 1.69-1.87 $\left(1 \mathrm{H}, \mathrm{m}, \mathrm{CH}_{\mathrm{A}} \mathrm{H}_{\mathrm{B}} \mathrm{CH}_{\mathrm{X}} \mathrm{S}\right), 2.13-2.28\left(1 \mathrm{H}, \mathrm{m}, \mathrm{CH}_{\mathrm{A}} H_{\mathrm{B}} \mathrm{CH}_{\mathrm{X}} \mathrm{S}\right.$; the coupling constants of $\mathrm{H}_{\mathrm{A}}$ and $\mathrm{H}_{\mathrm{B}}$ protons cannot be determined as signals are of higher order), $3.07(3 \mathrm{H}, \mathrm{s}$, $\left.\mathrm{NCH}_{3}\right) 3.55\left(2 \mathrm{H}, \mathrm{m}, \mathrm{CH}_{2} \mathrm{OH}\right), 4.09\left(2 \mathrm{H}, \mathrm{q}, J=7.2 \mathrm{~Hz}, \mathrm{CH}_{2} \mathrm{CH}_{3}\right), 4.12\left(1 \mathrm{H}, \mathrm{dd}, \mathrm{H}_{\mathrm{X}} ; J_{\mathrm{AX}}\right.$ and $J_{\mathrm{BX}}$ cannot be determined as the signal is buried below the quartet centered at $\left.\delta 4.09\right), 4.78$ $(1 \mathrm{H}, \mathrm{t}, J=5.0 \mathrm{~Hz}, \mathrm{OH}), 5.57(1 \mathrm{H}, \mathrm{s},=\mathrm{CH}),{ }^{13} \mathrm{C}$ NMR $\left(\mathrm{DMSO}-d_{6}\right): \delta 14.5\left(\mathrm{CH}_{2} \mathrm{CH}_{3}\right), 30.0$ $\left(\mathrm{NCH}_{3}\right), 36.1\left(\mathrm{CH}_{\mathrm{A}} \mathrm{H}_{\mathrm{B}}\right), 43.3\left(\mathrm{CH}_{\mathrm{X}}\right), 58.5\left(\mathrm{CH}_{2} \mathrm{OH}\right), 59.4\left(\mathrm{CH}_{2} \mathrm{CH}_{3}\right), 89.4(=\mathrm{CH}), 158.5$ $(\mathrm{C}=)$, $167.1\left(\mathrm{CO}_{\text {ester }}\right), 175.2\left(\mathrm{CO}_{\text {lactam }}\right)$; MS (CI): $\mathrm{m} / z 245\left(\mathrm{M}^{+}+1\right)$; UV (DMSO): $\lambda_{\max }(\varepsilon)$ $282.4 \mathrm{~nm},(22,600)$. Anal. Calcd for $\mathrm{C}_{10} \mathrm{H}_{15} \mathrm{NO}_{4} \mathrm{~S}: \mathrm{C}, 48.96 ; \mathrm{H}, 6.16 ; \mathrm{N}, 5.71 ; \mathrm{S}, 13.07$; Found: C, 48.95; H, 6.15; N, 5.74; S, 13.35.

\subsection{3. (Z)-(5-(2-Hydroxyethyl)-3-methyl-4-oxothiazolidin-2-ylidene)- $N$-(2- phenylethyl)ethanamide (12c).}

The title compound was obtained as a white solid in $78 \%$ yield $(40 \mathrm{mg})$ from $49 \mathrm{mg}(0.16$ mmol) of 11c and $25 \mathrm{mg}(0.011 \mathrm{~mL}, 0.18 \mathrm{mmol})$ of methyl iodide. Mp 145-146 ${ }^{\circ} \mathrm{C}$; IR $(\mathrm{KBr}): v_{\max } 3348$, ? jos neki signal 3074, 3026, 2923, 2882, 1685, 1640, 1581, 1545, 1475, 1423, 1332, 1298, 1213, 1128, 1128, 1075, 807, 780, 735, $701 \mathrm{~cm}^{-1} ;{ }^{1} \mathrm{H}$ NMR (DMSO- $d_{6}$ ): $\delta$ 1.62-1.79 $\left(1 \mathrm{H}, \mathrm{m}, \mathrm{CH}_{\mathrm{A}} \mathrm{H}_{\mathrm{B}} \mathrm{CH}_{\mathrm{X}} \mathrm{S}\right), 2.01-2.25\left(1 \mathrm{H}, \mathrm{m}, \mathrm{CH}_{\mathrm{A}} H_{\mathrm{B}} \mathrm{CH}_{\mathrm{X}} \mathrm{S}\right.$; the coupling constants of $\mathrm{H}_{\mathrm{A}}$ and $\mathrm{H}_{\mathrm{B}}$ protons cannot be determined as signals are of higher order), 2.72 $\left(2 \mathrm{H}, J=7.2 \mathrm{~Hz}, \mathrm{CH}_{2} \mathrm{Ph}\right), 3.02\left(3 \mathrm{H}, \mathrm{s}, \mathrm{NCH}_{3}\right) 3.30\left(2 \mathrm{H}, \mathrm{m}, \mathrm{CH}_{2} \mathrm{NH}\right), 3.54\left(2 \mathrm{H}, \mathrm{m}, \mathrm{CH}_{2} \mathrm{OH}\right)$, $3.97\left(1 \mathrm{H}, \mathrm{dd}, J_{\mathrm{AX}}=9.6 \mathrm{~Hz}, J_{\mathrm{BX}}=3.7 \mathrm{~Hz}, \mathrm{CH}_{\mathrm{A}} \mathrm{H}_{\mathrm{B}} \mathrm{CH} H_{\mathrm{X}} \mathrm{S}\right), 4.73(1 \mathrm{H}$, broad t, $J=5.2 \mathrm{~Hz}, \mathrm{OH})$, $5.58(1 \mathrm{H}, \mathrm{s},=\mathrm{CH}), 7.20-7.33(5 \mathrm{H}, \mathrm{m}, \mathrm{Ph}),{ }^{13} \mathrm{C}$ NMR (DMSO-d 6$): \delta 29.6\left(\mathrm{NCH}_{3}\right), 35.4$ $\left(\mathrm{CH}_{\mathrm{A}} \mathrm{H}_{\mathrm{B}}\right), 36.4\left(\mathrm{CH}_{2} \mathrm{Ph}\right), 40.0\left(\mathrm{CH}_{2} \mathrm{NH}\right), 42.4\left(\mathrm{CH}_{\mathrm{X}}\right), 58.3\left(\mathrm{CH}_{2} \mathrm{OH}\right), 93.2(=\mathrm{CH}), 126.0$ (p-Ph), $128.3(o-P h), 128.6(m-\mathrm{Ph}), 139.5\left(\mathrm{C}_{1}-\mathrm{Ph}\right), 151.4(\mathrm{C}=), 166.1\left(\mathrm{CO}_{\text {amide }}\right), 174.5$ (CO lactam); MS (CI): $m / z 245\left(\mathrm{M}^{+}+1\right)$; UV (DMSO): $\lambda_{\max }(\varepsilon) 282.4 \mathrm{~nm},(22,200)$. Anal. Calcd for $\mathrm{C}_{16} \mathrm{H}_{20} \mathrm{~N}_{2} \mathrm{O}_{3} \mathrm{~S}$ : C, 59.98; H, 6.29; N, 8.74; S, 10.01; Found: C, 59.94; H, 6.20; N, 8.57; S, 10.07 .

\subsection{4. (Z)-(5-(2-Hydroxyethyl)-3-methyl-4-oxothiazolidin-2-ylidene)ethanenitrile (12d)}

The title compound was obtained as a white solid in $80 \%$ yield $(43 \mathrm{mg})$ from $50 \mathrm{mg}(0.27$ mmol) of 11d and $42 \mathrm{mg}(0.019 \mathrm{~mL}, 0.30 \mathrm{mmol})$ of methyl iodide. Mp 106-107 ${ }^{\circ} \mathrm{C}$; IR $(\mathrm{KBr}): v_{\max } 3466,3076,2948,2888,2203,1718,1585,1424,1374,1317,1121,914,723$ 
$\mathrm{cm}^{-1} ;{ }^{1} \mathrm{H}$ NMR (DMSO-d $\left.)_{6}\right): \delta$ 1.78-1.96 $\left(1 \mathrm{H}, \mathrm{m}, \mathrm{CH}_{\mathrm{A}} \mathrm{H}_{\mathrm{B}} \mathrm{CH}_{\mathrm{X}} \mathrm{S}\right), 2.17-2.32(1 \mathrm{H}, \mathrm{m}$, $\mathrm{CH}_{\mathrm{A}} H_{\mathrm{B}} \mathrm{CH}_{\mathrm{X}} \mathrm{S}$; the coupling constants of $\mathrm{H}_{\mathrm{A}}$ and $\mathrm{H}_{\mathrm{B}}$ protons cannot be determined as signals are of higher order), $3.04\left(3 \mathrm{H}, \mathrm{s}, \mathrm{NCH}_{3}\right) 3.50-3.60\left(2 \mathrm{H}, \mathrm{m}, \mathrm{CH}_{2} \mathrm{OH}\right), 4.41(1 \mathrm{H}, \mathrm{dd}$, $J_{\mathrm{AX}}=9.8 \mathrm{~Hz}$ and $\left.J_{\mathrm{BX}}=3.8 \mathrm{~Hz}, \mathrm{CH}_{\mathrm{A}} \mathrm{H}_{\mathrm{B}} \mathrm{CH} H_{\mathrm{X}} \mathrm{S}\right), 4.82(1 \mathrm{H}, \mathrm{t}, J=5.0 \mathrm{~Hz}, \mathrm{OH}), 5.27(1 \mathrm{H}, \mathrm{s},=\mathrm{CH})$; ${ }^{13} \mathrm{C}$ NMR (DMSO- $\left.d_{6}\right): \delta 29.7\left(\mathrm{NCH}_{3}\right), 35.7\left(\mathrm{CH}_{\mathrm{A}} \mathrm{H}_{\mathrm{B}}\right), 45.7\left(\mathrm{CH}_{\mathrm{X}}\right), 58.5\left(\mathrm{CH}_{2} \mathrm{OH}\right), 67.1$ $(=\mathrm{CH}), 118.0(\mathrm{CN}), 160.4(\mathrm{C}=), 174.4\left(\mathrm{CO}_{\text {lactam }}\right) ; \mathrm{MS}(\mathrm{CI}): m / z 199\left(\mathrm{M}^{+}+1\right)$; UV (DMSO): $\lambda_{\max }(\varepsilon) 273.4 \mathrm{~nm},(19,000)$. Anal. Calcd for $\mathrm{C}_{8} \mathrm{H}_{10} \mathrm{~N}_{2} \mathrm{O}_{2} \mathrm{~S}: \mathrm{C}, 48.47 ; \mathrm{H}, 5.08 ; \mathrm{N}$, 14.13; S, 16.17; Found: C, 48.36; H, 5.06; N, 14.07; S, 16.33.

\subsection{5. (Z)-(5-Ethoxycarbonylmethyl-3-methyl-4-oxothiazolidin-2-ylidene)-1- phenylethanone (10a)}

According to general procedure for the preparation of 12a-d the title compound was obtained as a white solid in $86 \%$ yield $(90 \mathrm{mg})$ from $100 \mathrm{mg}(0.33 \mathrm{mmol})$ of 9a and $51 \mathrm{mg}$ $(0.022 \mathrm{~mL}, 0.36 \mathrm{mmol})$ of methyl iodide. $\mathrm{Mp} 114-115{ }^{\circ} \mathrm{C}$; IR $(\mathrm{KBr}): v_{\max } 3245,3069$, 2986, 2926, 1731, 1706, 1627, 1598, 1575, 1515, 1465, 1419, 1350, 1224, 1196, 1128, 1051, 1000, $791 \mathrm{~cm}^{-1} ;{ }^{1} \mathrm{H}$ NMR (DMSO-d $)$ : $\delta 1.17\left(3 \mathrm{H}, \mathrm{t}, J=7.0 \mathrm{~Hz}, \mathrm{CH}_{2} \mathrm{CH}_{3}\right), 2.94(2 \mathrm{H}$, $\mathrm{m}, \mathrm{CH}_{\mathrm{A}} H_{\mathrm{B}} \mathrm{CH}_{\mathrm{X}} \mathrm{S}$; the coupling constants of $\mathrm{H}_{\mathrm{A}}$ and $\mathrm{H}_{\mathrm{B}}$ protons cannot be determined as signals are of higher order), $3.28\left(3 \mathrm{H}, \mathrm{s}, \mathrm{NCH}_{3}\right), 4.09\left(2 \mathrm{H}, \mathrm{q}, J=7.0 \mathrm{~Hz}, \mathrm{CH}_{2} \mathrm{CH}_{3}\right), 4.31$ $\left(1 \mathrm{H}, \mathrm{dd}, J_{\mathrm{AX}}=7.0 \mathrm{~Hz}, J_{\mathrm{BX}}=4.6 \mathrm{~Hz}, \mathrm{CH}_{\mathrm{A}} \mathrm{H}_{\mathrm{B}} \mathrm{CH} \mathrm{X}_{\mathrm{X}} \mathrm{S}\right), 6.95(1 \mathrm{H}, \mathrm{s},=\mathrm{CH}), 7.48-7.64(3 \mathrm{H}, \mathrm{m}$, $p$ - and $m-\mathrm{Ph}), 8.04\left(2 \mathrm{H}, J_{o, m}=8.0 \mathrm{~Hz} ; J_{o, p}=1.6 \mathrm{~Hz}, o-\mathrm{Ph}\right) ;{ }^{13} \mathrm{C}$ NMR (DMSO- $\left.d_{6}\right): \delta 14.2$ $\left(\mathrm{CH}_{2} \mathrm{CH}_{3}\right), 30.5\left(\mathrm{NCH}_{3}\right), 36.3\left(\mathrm{CH}_{\mathrm{A}} \mathrm{H}_{\mathrm{B}}\right), 41.1\left(\mathrm{CH}_{\mathrm{X}}\right), 60.8\left(\mathrm{CH}_{2} \mathrm{CH}_{3}\right), 95.5(=\mathrm{CH}), 127.8$ $(m-\mathrm{Ph}), 128.8(o-\mathrm{Ph}), 132.4(p-\mathrm{Ph}), 138.3\left(\mathrm{C}_{1}-\mathrm{Ph}\right), 161.2(\mathrm{C}=), 170.3\left(\mathrm{CO}_{\text {ester }}\right), 174.5$ (CO lactam), 187.8 (CO ( $\left._{\text {ketone }}\right)$; MS (EI): $m / z$ (rel. intensity) $319\left(\mathrm{M}^{+}, 100\right), 302(3), 274(13)$, 245(100), 228(45), 168(63), 131(10), 105(67), 82(64), 77(56), 55(31); UV (DMSO): $\lambda_{\max }$ (ع) $336.0 \mathrm{~nm},(25,600)$. Anal. Calcd for $\mathrm{C}_{16} \mathrm{H}_{17} \mathrm{NO}_{4} \mathrm{~S}$ : C, 60.17; H, 5.36; N, 4.37; S, 10.04; Found: C, 59.88; H, 5.32; N, 4.39; S, 10.13 .

\subsection{General procedure for the preparation of $(Z)-2$-(tetrahydro-3-methylfuro[2,3- d] thiazol-2-ylidene derivatives 13a-d}

To a solution containing $0.1 \mathrm{mmol}$ of $\mathrm{N}$-methyl-4-oxothiazolidine alcohol 12 in $5 \mathrm{~mL}$ of dry ethanol, $0.23 \mathrm{mmol}_{\text {of }} \mathrm{NaBH}_{4}$ in $5 \mathrm{~mL}$ of ethanol was added dropwise ( 10 min) with vigorous stirring at $\mathrm{rt}$. After the addition was complete, the yellow reaction mixture was stirred for an additional $4 \mathrm{~h}$ until complete disappearance of starting material (TLC), whereupon the solution became colorless. The mixture was concentrated under reduced pressure to a small volume $(\sim 2 \mathrm{~mL})$. Then, a $5 \%$ aqueous solution of ammonium chloride was added, followed by $\mathrm{CHCl}_{3}$ and the stirring was continued for $30 \mathrm{~min}$. The aqueous layer was extracted with $\mathrm{CHCl}_{3}$ and combined organic fractions were washed with water, dried over $\mathrm{Na}_{2} \mathrm{SO}_{4}$ and concentrated under reduced pressure. The crude residue was purified by thin-layer chromatography (toluene/ethyl acetate as eluant; 40:60, v/v). Annalytically pure samples 13a-d were obtained by crystallization from $n$-hexane (13b and 13d), or $n$-hexane/toluene mixture (13a and 13c).

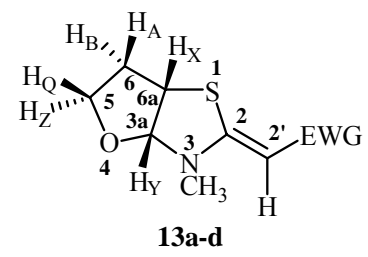




\subsection{1. cis-(Z)-(3-Methyltetrahydrofuro[2,3-d]thiazol-2(3H)-ylidene)-1- phenylethanone (13a)}

The title compound was obtained as a white solid in 56\% yield $(14.7 \mathrm{mg})$ from $29 \mathrm{mg}(0.1$ mmol) of 9a. Mp 121-122 ${ }^{\circ} \mathrm{C}$; IR (KBr): $v_{\max } 3053,2974,2939,1602,1571,1525,1433$, $1355,1264,1213,1084,1061,1028,973,801,727,691 \mathrm{~cm}^{-1} ;{ }^{1} \mathrm{H}$ NMR (DMSO- $d_{6}$ ): $\delta$ $2.12\left(1 \mathrm{H}\right.$, dd broad, $\left.J_{\mathrm{AB}}=12.6 \mathrm{~Hz}, J_{\mathrm{AQ}}=4.8 \mathrm{~Hz}, J_{\mathrm{AX}}=0.9 \mathrm{~Hz}, J_{\mathrm{Az}}=1.0 \mathrm{~Hz}, \mathrm{CH}_{\mathrm{A}} \mathrm{H}_{\mathrm{B}} \mathrm{CH}_{\mathrm{X}} \mathrm{S}\right)$, $2.33\left(1 \mathrm{H}, \mathrm{ddt}, J_{\mathrm{AB}}=12.9 \mathrm{~Hz}, J_{\mathrm{BQ}}=11.1 \mathrm{~Hz}, J_{\mathrm{BX}}=J_{\mathrm{BZ}}=7.4 \mathrm{~Hz}, \mathrm{CH}_{\mathrm{A}} H_{\mathrm{B}} \mathrm{CH}_{\mathrm{X}} \mathrm{S}\right), 3.10(3 \mathrm{H}, \mathrm{s}$, $\left.\mathrm{NCH}_{3}\right), 3.83\left(1 \mathrm{H}, \mathrm{ddd}, J_{\mathrm{BQ}}=11.1 \mathrm{~Hz}, J_{\mathrm{QZ}}=8.8 \mathrm{~Hz}, J_{\mathrm{AQ}}=5.0 \mathrm{~Hz}, \mathrm{CH}_{\mathrm{Q}} \mathrm{H}_{\mathrm{Z}} \mathrm{O}\right), 4.02(1 \mathrm{H}$, ddd, $\left.J_{\mathrm{QZ}}=8.8 \mathrm{~Hz}, J_{\mathrm{BZ}}=7.4 \mathrm{~Hz}, J_{\mathrm{Az}}=1.0 \mathrm{~Hz}, \mathrm{CH}_{\mathrm{Q}} H_{\mathrm{Z}} \mathrm{O}\right), 4.12\left(1 \mathrm{H} \mathrm{ddd}, 1 \mathrm{H}, J_{\mathrm{BX}}=7.4 \mathrm{~Hz}, J_{\mathrm{XY}}=6.6\right.$ $\left.\mathrm{Hz}, J_{\mathrm{AX}}=0.9 \mathrm{~Hz}, \mathrm{OCH}_{\mathrm{Y}} \mathrm{CH}_{\mathrm{X}} \mathrm{S}\right), 5.67\left(1 \mathrm{H}, \mathrm{d}, J_{\mathrm{XY}}=6.6 \mathrm{~Hz}, \mathrm{OCH}_{\mathrm{Y}} \mathrm{CH}_{\mathrm{X}} \mathrm{S}\right), 6.08(1 \mathrm{H}, \mathrm{s},=\mathrm{CH})$, 7.36-7.47 $(3 \mathrm{H}, \mathrm{m}, m-$ and $p-\mathrm{Ph}), 7.90-7.95(2 \mathrm{H}, \mathrm{m}, o-\mathrm{Ph}) ;{ }^{13} \mathrm{C} \mathrm{NMR}\left(\mathrm{CDCl}_{3}\right): \delta 33.7$ $\left(\mathrm{NCH}_{3}\right), 35.2\left(\mathrm{CH}_{\mathrm{A}} \mathrm{H}_{\mathrm{B}}\right), 44.6\left(\mathrm{CH}_{\mathrm{X}}\right), 65.8\left(\mathrm{CH}_{\mathrm{Q}} \mathrm{H}_{\mathrm{Z}}\right), 87.5(=\mathrm{CH}), 99.1\left(\mathrm{CH}_{\mathrm{Y}}\right), 127.2(m-$ $\mathrm{Ph}), 128.2(o-\mathrm{Ph}), 131.0(p-\mathrm{Ph}), 139.7\left(\mathrm{C}_{1}-\mathrm{Ph}\right), 165.7(\mathrm{C}=), 186.9\left(\mathrm{CO}_{\text {ketone }}\right)$; MS (EI, 70 $\mathrm{eV}): m / z$ (rel. intensity): $261\left(\mathrm{M}^{+}, 57\right), 260$ (100), 245 (34), 191 (20), 184 (42), 163 (32), 105 (97), 86 (39), 82 (58), 51 (26); UV (DMSO): $\lambda_{\max }$ (ع) $338.0 \mathrm{~nm}(19,700)$; Anal. Calcd for $\mathrm{C}_{14} \mathrm{H}_{15} \mathrm{NO}_{2} \mathrm{~S}$ : C, 64.34; H, 5.78; N, 5.36; S, 12.27; Found: C, 64.24; H, 5.82; N, 5.30; S, 12.59 .

\subsection{2. cis-(Z)-Ethyl (3-methyltetrahydrofuro[2,3-d]thiazol-2(3H)-ylidene)acetate (13b)}

The title compound was obtained as a white solid in $36 \%$ yield $(20 \mathrm{mg})$ from $60 \mathrm{mg}(0.25$ mmol) of 9a. Mp 48-49 ${ }^{\circ} \mathrm{C}$; IR (KBr): $v_{\max }$ 3068, 2976, 2948, 2884, 1672, 1567, 1437, 1367, 1243, 1156, 1092, 1046, 1000, 963, 896, 779, $713 \mathrm{~cm}^{-1} ;{ }^{1} \mathrm{H}$ NMR (DMSO- $d_{6}$ ): $\delta$ $1.26\left(3 \mathrm{H}, \mathrm{t}, J=7.1 \mathrm{~Hz}, \mathrm{CH}_{2} \mathrm{CH}_{3}\right) 2.11\left(1 \mathrm{H}\right.$, dd broad $J_{\mathrm{AB}}=12.9 \mathrm{~Hz}, J_{\mathrm{AQ}}=4.9 \mathrm{~Hz}, J_{\mathrm{AX}} \sim 0 \mathrm{~Hz}$, $\left.J_{\mathrm{Az}}=1.0 \mathrm{~Hz}, \mathrm{CH}_{\mathrm{A}} \mathrm{H}_{\mathrm{B}} \mathrm{CH}_{\mathrm{X}} \mathrm{S}\right), 2.29\left(1 \mathrm{H}, \mathrm{ddt}, J_{\mathrm{AB}}=12.9 \mathrm{~Hz}, J_{\mathrm{BQ}}=11.0 \mathrm{~Hz}, J_{\mathrm{BX}}=J_{\mathrm{BZ}}=7.2 \mathrm{~Hz}\right.$, $\left.\mathrm{CH}_{\mathrm{A}} H_{\mathrm{B}} \mathrm{CH}_{\mathrm{X}} \mathrm{S}\right), 2.94\left(3 \mathrm{H}, \mathrm{s}, \mathrm{NCH}_{3}\right), 3.83\left(1 \mathrm{H}, \mathrm{ddd}, J_{\mathrm{BQ}}=11.0 \mathrm{~Hz}, J_{\mathrm{QZ}}=8.6 \mathrm{~Hz}, J_{\mathrm{AQ}}=4.9 \mathrm{~Hz}\right.$, $\left.\mathrm{C}_{\mathrm{Q}} \mathrm{H}_{\mathrm{Z}} \mathrm{O}\right), 3.98\left(1 \mathrm{H}, \mathrm{ddd}, J_{\mathrm{QZ}}=8.6 \mathrm{~Hz}, J_{\mathrm{Bz}}=7.2 \mathrm{~Hz}, J_{\mathrm{AZ}}=1.0 \mathrm{~Hz}, \mathrm{CH}_{\mathrm{Q}} H_{\mathrm{Z}} \mathrm{O}\right), 4.10(1 \mathrm{H} \mathrm{dd}$, $\left.1 \mathrm{H}, J_{\mathrm{BX}}=7.2 \mathrm{~Hz}, J_{\mathrm{XY}}=6.2 \mathrm{~Hz}, \mathrm{OCH}_{\mathrm{Y}} \mathrm{CH}_{\mathrm{X}} \mathrm{S}\right), 4.15\left(2 \mathrm{H}, \mathrm{q}, J=7.2 \mathrm{~Hz}, \mathrm{CH}_{2} \mathrm{CH}_{3}\right), 4.84(1 \mathrm{H}, \mathrm{s}$, $=\mathrm{CH}), 5.61\left(1 \mathrm{H}, \mathrm{d}, J_{\mathrm{XY}}=6.2 \mathrm{~Hz}, \mathrm{OCH}_{\mathrm{Y}} \mathrm{CH}_{\mathrm{X}} \mathrm{S}\right) ;{ }^{13} \mathrm{C} \mathrm{NMR}\left(\mathrm{CDCl}_{3}\right): \delta 14.5\left(\mathrm{CH}_{2} \mathrm{CH}_{3}\right), 33.0$ $\left(\mathrm{NCH}_{3}\right), 35.3\left(\mathrm{CH}_{\mathrm{A}} \mathrm{H}_{\mathrm{B}}\right), 44.4\left(\mathrm{CH}_{\mathrm{X}}\right), 59.1\left(\mathrm{CH}_{2} \mathrm{CH}_{3}\right), 65.6\left(\mathrm{CH}_{\mathrm{Q}} \mathrm{H}_{\mathrm{Z}}\right), 79.6(=\mathrm{CH}), 99.5$ $\left(\mathrm{CH}_{\mathrm{Y}}\right), 162.9(\mathrm{C}=), 169.1$ ( $\left.\mathrm{CO}_{\text {ester }}\right)$; MS (CI): $230\left(\mathrm{M}^{+}+1\right)$ ); UV (DMSO): $\lambda_{\max }(\varepsilon) 279.0$ $\mathrm{nm}(23,400)$; Anal. Calcd for $\mathrm{C}_{10} \mathrm{H}_{14} \mathrm{NO}_{3} \mathrm{~S}$ : C, 52.38; H, 6.59; N, 6.11; S, 13.98; Found: C, $52.24 ; \mathrm{H}, 6.61 ; \mathrm{N}, 6.07 ; \mathrm{S}, 14.00$.

\subsection{3. cis-(Z)-(3-Methyltetrahydrofuro[2,3-d]thiazol-2(3H)-ylidene)- $N$-phenylacet- amide (13c)}

The title compound was obtained as a white solid in $40 \%$ yield $(28 \mathrm{mg})$ from $75 \mathrm{mg}(0.23$ mmol) of 12c. Mp 151-153 ${ }^{\circ} \mathrm{C}$; IR (KBr): $v_{\max } 3303,3063,3026,2925,2875,1627,1561$, 1436, 1383, 1254, 1196, 1082, 1028, 989, 778, 750, $703 \mathrm{~cm}^{-1} ;{ }^{1} \mathrm{H}$ NMR (DMSO- $d_{6}$ ): $\delta$ $2.10\left(1 \mathrm{H}\right.$, dd broad, $\left.J_{\mathrm{AB}}=12.6 \mathrm{~Hz}, J_{\mathrm{AQ}}=5.0 \mathrm{~Hz}, J_{\mathrm{AX}} \sim 0 \mathrm{~Hz}, J_{\mathrm{Az}}=1.2 \mathrm{~Hz}, \mathrm{CH}_{\mathrm{A}} \mathrm{H}_{\mathrm{B}} \mathrm{CH}_{\mathrm{X}} \mathrm{S}\right), 2.26$ $\left(1 \mathrm{H}, \mathrm{ddt}, J_{\mathrm{AB}}=12.6 \mathrm{~Hz}, J_{\mathrm{BQ}}=10.7 \mathrm{~Hz}, J_{\mathrm{BX}}=J_{\mathrm{BZ}}=7.2 \mathrm{~Hz}, \mathrm{CH}_{\mathrm{A}} H_{\mathrm{B}} \mathrm{CH}_{\mathrm{X}} \mathrm{S}\right), 2.83(2 \mathrm{H}, \mathrm{t}, J=7.0$ $\left.\mathrm{Hz}, \mathrm{CH}_{2} \mathrm{Ph}\right), 2.88\left(3 \mathrm{H}, \mathrm{s}, \mathrm{NCH}_{3}\right), 3.56\left(2 \mathrm{H}, \mathrm{m}, J=7.0\right.$ and $\left.6.2 \mathrm{~Hz}, \mathrm{CH}_{2} \mathrm{NH}\right), 3.86(1 \mathrm{H}$, ddd, $\left.J_{\mathrm{BQ}}=10.8 \mathrm{~Hz}, J_{\mathrm{QZ}}=8.6 \mathrm{~Hz}, J_{\mathrm{AQ}}=5.0 \mathrm{~Hz}, \mathrm{CH}_{\mathrm{Q}} \mathrm{H}_{\mathrm{Z}} \mathrm{O}\right), 3.95\left(1 \mathrm{H}, \mathrm{ddd}, J_{\mathrm{QZ}}=8.6 \mathrm{~Hz}, J_{\mathrm{BZ}}=7.2 \mathrm{~Hz}\right.$, $\left.J_{\mathrm{AZ}}=1.2 \mathrm{~Hz}, \mathrm{CH}_{\mathrm{Q}} H_{\mathrm{Z}} \mathrm{O}\right), 4.06\left(1 \mathrm{H} \mathrm{dd}, 1 \mathrm{H}, J_{\mathrm{BX}}=7.2 \mathrm{~Hz}, J_{\mathrm{XY}}=6.2 \mathrm{~Hz}, \mathrm{OCH}_{\mathrm{Y}} H_{\mathrm{X}} \mathrm{S}\right), 4.67$ $(1 \mathrm{H}, \mathrm{s},=\mathrm{CH}), 5.55\left(1 \mathrm{H}, \mathrm{d}, J_{\mathrm{XY}}=6.2 \mathrm{~Hz}, \mathrm{OCH}_{\mathrm{Y}} \mathrm{CH}_{\mathrm{X}} \mathrm{S}\right), 7.19-7.30(5 \mathrm{H}, \mathrm{m}, \mathrm{Ph}) ;{ }^{13} \mathrm{C} \mathrm{NMR}$ $\left(\mathrm{CDCl}_{3}\right): \delta 29.6\left(\mathrm{NCH}_{3}\right), 35.3\left(\mathrm{CH}_{\mathrm{A}} \mathrm{H}_{\mathrm{B}}\right), 36.3\left(\mathrm{CH}_{2} \mathrm{Ph}\right), 40.5\left(\mathrm{CH}_{2} \mathrm{NH}\right), 44.6\left(\mathrm{CH}_{\mathrm{X}}\right), 65.6$ $\left(\mathrm{OCH}_{2}\right), 82.3(=\mathrm{CH}), 99.1\left(\mathrm{CH}_{\mathrm{Y}}\right), 126.3(p-\mathrm{Ph}), 128.5(o-\mathrm{Ph}), 128.9(m-\mathrm{Ph}), 139.5\left(\mathrm{C}_{1}-\mathrm{Ph}\right)$, 
$166.0(\mathrm{C}=)$, $162.1\left(\mathrm{CO}_{\text {amide }}\right)$; $\mathrm{MS}(\mathrm{ESI})$ : Calcd for $\mathrm{C}_{16} \mathrm{H}_{21} \mathrm{~N}_{2} \mathrm{O}_{2} \mathrm{~S}$ : $305.13182\left(\mathrm{M}+\mathrm{H}^{+}\right)$; Found: 305.1318; UV (DMSO): $\lambda_{\max }(\varepsilon) 277.0 \mathrm{~nm}(12,900)$.

\subsection{4. cis-(Z)-(3-Methyltetrahydrofuro[2,3-d]thiazol-2(3H)-ylidene)acetonitrile (13d)}

The title compound was obtained as a white solid in $40 \%$ yield $(7.5 \mathrm{mg})$ from $20 \mathrm{mg}(0.1$ mmol) of 12d. Mp 59-61 ${ }^{\circ} \mathrm{C}$; IR (KBr): $v_{\max } 3061,2927,2860,2187,1578,1423,1395$, 1310, 1259, 1092, 1034, 964, 896, 859, $691 \mathrm{~cm}^{-1} ;{ }^{1} \mathrm{H}$ NMR (DMSO- $\left.d_{6}\right): \delta 2.12(1 \mathrm{H}, \mathrm{dd}$ broad, $\left.J_{\mathrm{AB}}=13.3 \mathrm{~Hz}, J_{\mathrm{AQ}}=5.1 \mathrm{~Hz}, J_{\mathrm{AX}}=1.0 \mathrm{~Hz}, J_{\mathrm{AZ}}=1.1 \mathrm{~Hz}, \mathrm{CH}_{\mathrm{A}} \mathrm{H}_{\mathrm{B}} \mathrm{CH}_{\mathrm{X}} \mathrm{S}\right), 2.32(1 \mathrm{H}$, ddt, $\left.J_{\mathrm{AB}}=13.3 \mathrm{~Hz}, J_{\mathrm{BQ}}=11.0 \mathrm{~Hz}, J_{\mathrm{BX}}=J_{\mathrm{BZ}}=7.4 \mathrm{~Hz}, \mathrm{CH}_{\mathrm{A}} H_{\mathrm{B}} \mathrm{CH}_{\mathrm{X}} \mathrm{S}\right), 2.88\left(3 \mathrm{H}, \mathrm{s}, \mathrm{NCH}_{3}\right) 3.88(1 \mathrm{H}$, ddd, $\left.J_{\mathrm{BQ}}=11.0 \mathrm{~Hz}, J_{\mathrm{QZ}}=8.9 \mathrm{~Hz}, J_{\mathrm{AQ}}=5.1 \mathrm{~Hz}, \mathrm{CH}_{\mathrm{Q}} \mathrm{H}_{\mathrm{Z}} \mathrm{O}\right), 3.94(1 \mathrm{H}, \mathrm{s},=\mathrm{CH}), 4.04(1 \mathrm{H}, \mathrm{ddd}$, $\left.J_{\mathrm{QZ}}=8.9 \mathrm{~Hz}, J_{\mathrm{BZ}}=7.4 \mathrm{~Hz}, J_{\mathrm{Az}}=1.2 \mathrm{~Hz}, \mathrm{CH}_{\mathrm{Q}} H_{\mathrm{Z}} \mathrm{O}\right), 4.25\left(1 \mathrm{H}, \mathrm{ddd}, J_{\mathrm{XY}}=6.6 \mathrm{~Hz}, J_{\mathrm{BX}}=7.4 \mathrm{~Hz}\right.$, $\left.J_{\mathrm{AX}}=1 \mathrm{~Hz}, \mathrm{CH}_{\mathrm{A}} \mathrm{H}_{\mathrm{B}} \mathrm{CH} H_{\mathrm{X}} \mathrm{S}\right), 4.82(1 \mathrm{H}, \mathrm{t}, J=5.0 \mathrm{~Hz}, \mathrm{OH}),{ }^{13} \mathrm{C}$ NMR (DMSO- $\left.d_{6}\right): \delta 29.7$ $\left(\mathrm{NCH}_{3}\right), 35.7\left(\mathrm{CH}_{\mathrm{A}} \mathrm{H}_{\mathrm{B}}\right), 45.7\left(\mathrm{CH}_{\mathrm{X}}\right), 58.5\left(\mathrm{CH}_{2} \mathrm{OH}\right), 67.1(=\mathrm{CH}), 118.0(\mathrm{CN}), 160.4(\mathrm{C}=)$, 174.4 (CO lactam); MS (CI): $m / z 199\left(\mathrm{M}^{+}+1\right)$; UV (DMSO): $\lambda_{\max }(\varepsilon) 264.0 \mathrm{~nm},(26,100)$. Anal. Calcd for $\mathrm{C}_{8} \mathrm{H}_{10} \mathrm{~N}_{2} \mathrm{OS}$ : C, 52.7; H, 5.53; N, 15.37; S, 17.59; Found: C, 52.77; H, $5.59 ; \mathrm{N}, 15.06 ; \mathrm{S}, 17.56$.

\subsection{Crystal structure determination of compounds 10a and 13a}

Data were collected with a Siemens SMART CCD area detector, using graphite monochromatized MoK $\alpha$ radiation $(\lambda=0.71073 \AA)$. The structures were solved by direct methods using SHELXS ${ }^{21}$ and refined on $\mathrm{F}^{2}$, using all data, by full-matrix least-squares procedures using SHELXTL. ${ }^{22}$ Hydrogen atoms were included in calculated positions, with isotropic displacement parameters 1.2 times the isotropic equivalent of the carrier carbons.

Full tables of atom coordinates, thermal parameters, and bond lengths and angles have been deposited at the Cambridge Crystallographic Data Centre. CCDC 265572 and 265573 contains the supplementary crystallographic data for this paper. These data can be obtained free of charge at www.ccdc.cam.ac.uk/conts/retrieving.html [or from the Cambridge Crystallographic Data Centre, 12 Union Road, Cambridge CB2 1EZ, UK; fax: (internat.) + 44-1223/336-033; Email: deposit@ccdc.cam.ac.uk].

Crystal data for 10a: $\mathrm{C}_{16} \mathrm{H}_{17} \mathrm{NO}_{4} \mathrm{~S}$, MW 319.37, monoclinic, $\mathrm{P} 2{ }_{1} / \mathrm{c}, a=12.2698(16), b=$ 12.5920(16), $c=10.1610(13) \AA, \beta=100.097(2)^{\circ}, \mathrm{V}=1545.6(3) \AA^{3}, \mathrm{Z}=4, \mathrm{~T}=-183^{\circ} \mathrm{C}$,

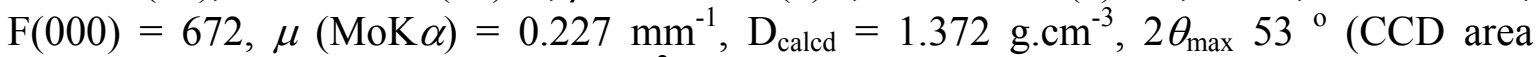
detector, $99.2 \%$ completeness), $\mathrm{wR}\left(\mathrm{F}^{2}\right)=0.0756$ (all 3151 data), $\mathrm{R}=0.0327$ (2135 data with $\mathrm{I}>2 \sigma)$.

Crystal data for 13a: $\mathrm{C}_{14} \mathrm{H}_{15} \mathrm{NO}_{2} \mathrm{~S}$, MW 261.33, monoclinic, $\mathrm{P} 2{ }_{1} / \mathrm{c}, a=21.7289(13), b=$ 7.7567(4), $c=15.5614(9) \AA, \beta=110.413(1)^{\circ}, \mathrm{V}=2458.1(2) \AA^{3}, \mathrm{Z}=8, \mathrm{~T}=-183{ }^{\circ} \mathrm{C}$,

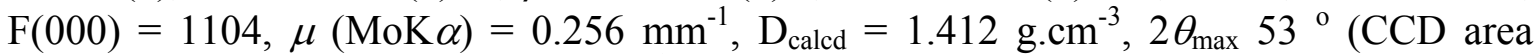
detector, $99.5 \%$ completeness), $\mathrm{wR}\left(\mathrm{F}^{2}\right)=0.0828$ (all 5018 data), $\mathrm{R}=0.0311$ (4543 data with $\mathrm{I}>2 \sigma)$.

\section{Acknowledgment.}

Partial financial support by the Ministry of Science, Technology and Development of the Republic of Serbia, grant no. 1709 (to R.M.), is acknowledged. 


\section{References}

1. (a) Royer, J.; Bonin, M.; Micouin, L. Chem. Rev. 2004, 104, 2311-2352. (b) Maryanoff, B. E.; Zhang, H.-C.; Cohen, J. H.; Turchi, I. J.; Maryanoff, C. A. Chem. Rev. 2004, 104, 1431-1628. (c) Specamp, W. N.; Moolenaar, M. J. Tetrahedron 2000, 56, 3817-3856.

2. (a) Higashiyama, K.; Kyo, H.; Takahashi, H. Synlett 1998, 489-490. (b) Agami, C.; Couty, F.; Lequesne, C. Tetrahedron Lett. 1994, 35, 3309-3312. (c) Keller, M.; Lehmann, C.; Mutter, M. Tetrahedron 1999, 55, 413-422.

3. (a) Geyer, A.; Moser, F. Eur. J. Org. Chem. 2000, 1113-1120. (b) Juaristi, E.; Anzorena, J. L.; Boog, A.; Madigal, D.; Seebach, D.; Garcia-Baez, E. V.; GarciaBarradas, O.; Gordillo, B.; Kramer, A.; Steiner, I.; Zürcher, S. J. Org. Chem. 1995, 60, 6408-6415. (c) Stragies, R.; Blechert, S. J. Am. Chem. Soc. 2000, 122, 95849591. (d) Mizutani, N.; Chiou, W.-H.; Ojima, I. Org. Lett. 2002, 4, 4575-4578. (e) Murer, P.; Rheiner, B.; Juaristi, E.; Seebach, D. Heterocycles 1994, 39, 319-344.

4. Kayakiri, H.; Kasahara, C.; Oku, T.; Hashimoto, M. Tetrahedron Lett. 1990, 31, 225-226.

5. (a) Veenestra, S. J.; Hauser, K.; Schilling, W.; Betschart, C.; Ofner, S. Bioorg. Med. Chem. Lett. 1996, 6, 3029-3034. (b) Cox, E. D.; Cook, J. M. Chem. Rev. 1995, 95, 1797-1842.

6. (a) Lee, T. B. K.; Wong, G. S. K. J. Org. Chem. 1991, 56, 872-875. (b) Pei, X.-F.; Greig, N. H.; Flippen-Anderson, J. L.; Bi, S.; Brossi, A. Helv. Chim. Acta 1994, 77, 1412-1422. (c) Vojkowski, T.; Weichsel, A.; Patek, M. J. Org. Chem. 1998, 63, 3162-3163. (d) Abe, H.; Aoyagi, S.; Kibayashi, C. Angew. Chem., Int. Ed. 2002, 41, 3017-3020. (e) Klaver, W. J.; Moolenaar, M. J.; Hiemstra, H.; Speckamp, W. N. Tetrahedron 1988, 44, 3805-3818. (f) Bahajaj, A. A.; Moore, M. H.; Vernon, J. M. Tetrahedron 2004, 60, 1235-1246.

7. (a) Sheehan, S. M.; Beall, L. S.; Padwa, A. Tetrahedron Lett. 1998, 39, 4761-4764.

(b) Tanis, S. P.; Deaton, M. V.; Dixon, L. A.; McMills, M. C.; Raggon, J. W.;

Collins, M. A. J. Org. Chem 1998, 63, 6914-6928. (c) Metais, E.; Overman, L. E.; Rodriguez, M. I.; Stearns, B. A. J. Org. Chem. 1997, 62, 9210-9216

8. (a) Hart, D. J. J. Org. Chem. 1981, 46, 367-373. (b) Hart, D. J. J. Am. Chem. Soc. 1980, 102, 397-398. (c) Winterfeldt, E. Synthesis, 1975, 617-630. (d) Fasseur, D.; Rigo, B.; Cauliez, P.; Debacker, M.; Couturier, D. Tetrahedron Lett. 1990, 31, 1713-1716. (e) Gupton, J. T.; Clough, S. C.; Miller, R. B.; Norwood, B. K.; Hickenboth, C. R.; Chertudi, I. B.; Cutro, S. R.; Petrich, S. A.; Hicks, F. A.; Wilkinson, D. R.; Sikorski, J. A. Tetrahedron 2002, 58, 5467-5474. (f) Padwa, A.; Kappe, O.; Cochran, J. E.; Snyder, J. P. J. Org. Chem. 1997, 62, 2786-2797.

9. Overman, L. E.; Fukaya, C. J. Am. Chem. Soc. 1980, 102, 1454-1456.

10. (a) Marković, R.; Baranac, M. Heterocycles 1998, 48, 893-903. (b) Marković, R.; Baranac, M.; Džambaski, Z.; Stojanović, M.; Steel, P. J. Tetrahedron 2003, 59, 7803-7810.

11. Marković, R.; Baranac, M.; Stojanović, M. Synlett 2004, 1034-1038.

12. (a) Takamizawa, A.; Hirai, K.; Hamashima, Y.; Matsumoto, S. Tetrahedron Lett. 1967, 5071-5075. (b) Karimian, K.; Askari, M.; Farahani, M.; Sachinvala, N. Synthesis 1981, 48-49. (c) Brown, H. J.; Shaw, G.; Wright, D. J. Chem. Soc., Perkin Trans. 1 1981, 657-660. (d) Robins, M. J.; Currie, B. L.; Robins, R. K.; Broom, A. D. Can. J. Chem. 1971, 49, 3067-3068. (e) Maruyama, T.; Wotring, L. L.; Townsend, L. B. J. Med. Chem. 1983, 26, 25-29.

13. Pujari, H. K. Adv. Heterocycl. Chem. 1990, 49, 1-116. 
14. (a) Calvo, L.; Gonzáles-Ortega, A.; Sanudo, M. C. Synthesis 2002, 2450-2456. (b) Prugh, J.; Deana, A. A. Tetrahedron Lett. 1988, 29, 37-40. (c) Greenhill, J. V.;

Ramli, M.; Tomassini, T. J. Chem. Soc., Perkin Trans.1, 1975, 588-591.

15. Marković, R.; Baranac, M.; Jovetić, S. Tetrahedron Lett. 2003, 44, 7087-7090.

16. (a) Chiara, J. L.; Gómez-Sánchez, A.; Marcos, E. S.; Bellanato, J. J. Chem. Soc., Perkin Trans. 2 1990, 385-392. (b) Ostercamp, D. L.; Taylor, P. J. J. Chem. Soc., Perkin Trans. 2 1985, 1021-1028.

17. Kleinpeter, E.; Klod, S.; Rudorf, W.-D. J. Org. Chem. 2004, 69, 4317-4329.

18. Marković, R.; Rašović, A.; Baranac, M.; Stojanović, M.; Steel, P. J.; Jovetić, S. J. Serb. Chem. Soc. 2004, 69, 909-918.

19. (a) Miller, S. A.; Chamberlin, A. R. J. Am. Chem. Soc. 1990, 112, 8100-8112. (b) Micouin, L.; Diez, A.; Castells, J.; López, D.; Rubiralta, M.; Quirion, J.-C.; Husson, H.-P. Tetrahedron Lett. 1995, 36, 1693-1696. (c) Meyers, A. I.; Lefker, B. A.; Wanner, K. T.; Aitken, R. A. J. Org. Chem. 1986, 51, 1936-1938. (d) Dijkink, J.; Speckamp, W. N. Tetrahedron Lett. 1977, 935-938. (e) Fukuyama, T.; Nunes, J. J. J. Am. Chem. Soc. 1988, 110, 5196-5198.

20. (a) Manteca, I.; Sotomayor, N.; Villa, M.-J.; Lete, E. Tetrahedron Lett. 1996, 37, 7841-7844. (b) Collado, M. I.; Manteca, I.; Sotomayor, N.; Villa, M.-J.; Lete, E. J. Org. Chem. 1997, 62, 2080-2092.

21. Sheldrick G.M. Acta Crystallogr. Sect. A 1990, 46, 467.

22. Sheldrick G.M. SHELXTL; Bruker Analytical X-ray Systems, 1997. 